\title{
Ruang Terbuka Hijau dalam Mitigasi Perubahan Iklim Green Open Space in Climate Change Mitigation
}

\author{
Yusriani Sapta Dewi \\ Koordinator Aliansi Perempuan untuk Pembangunan Berkelanjutan
}

Abstract

\begin{abstract}
Climate change is any substantial change in Earth's climate that lasts for an extended period of time. Global warming refers to climate change that causes an increase in the average temperature of the lower atmosphere. Global warming is the combined result of anthropogenic (human-caused) emissions of greenhouse gases and changes in solar irradiance, while climate change refers to any change in the state of the climate that can be identified by changes in the average and/or the variability of its properties (e.g., temperature, precipitation), and that persists for an extended period, typically decades or longer. Green open space is one of solution for climate change mitigation.
\end{abstract}

Keywords : Ruang terbuka hijau, pemanasan global, perubahan iklim

\section{PENDAHULUAN}

\section{Isu Perubahan Iklim}

Sistem pemanasan ilmiah Termostat Global ditentukan oleh jumlah energi matahari yang ditahan oleh atmosfer Bumi. Tanah dan air menyerap sinar matahari yang masuk dan mengubahnya menjadi panas, yang dilepaskan kembali ke udara sebagai radiasi inframerah. Seperti dinding-dinding kaca dari sebuah rumah kaca, gas-gas atmosfer, terutama $\mathrm{CO}_{2}$ (carbon dioksida), uap air dan metana menjebak sebagian besar dari panas yang membumbung dan menahannya di atmosfer yang lebih rendah. Tanpa proses alamiah ini, yang biasanya disebut efek rumah kaca, temperatur rata-rata bumi akan menggantung pada angka $-18^{\circ} \mathrm{C}$ yang beku, bukannya $14,5^{\circ} \mathrm{C}$ seperti saat ini (O’Neill, T. et al., 2007)

Meningkatnya suhu rata-rata permukaan bumi menyebabkan terjadinya perubahan pada unsur-unsur iklim lainnya. Iklim sedang berubah sudah menjadi kenyataan saat ini. Bukti ilmiahnya jelas yaitu meningkatnya temperatur permukaan bumi. Suhu rata-rata permukaan bumi dikumpulkan dari ribuan lokasi di darat dan laut, meningkat $0,74^{0} \mathrm{C}$ dalam seabad terakhir. Tiga perempat kenaikan itu terjadi pada tiga dasawarsa terakhir; 11 dari 12 tahun terpanas terjadi sejak 1995. Hasil penelitian menunjukkan bahwa terjadinya peningkatan suhu cukup ekstrem sebagai akibat meningkatnya konsentrasi gas rumah kaca terutama $\mathrm{CO}_{2}$ di atmosfer (Kunzig, 2008:29). Konsentrasi gas rumah kaca (GRK) menyebabkan suhu bumi meningkat sehingga terjadi pemanasan global. Berbagai peristiwa membuktikan adanya tanda-tanda peningkatan suhu tersebut; meskipun di antaranya memang kurang terasa. Mencairnya es di kutub Utara dan kutub Selatan merupakan salah satu tanda peningkatan suhu. Diperkirakan tahun 2100, gletser yang menyelimuti pegunungan Himalaya seluas $\pm 300 \mathrm{~km}^{2}$ akan mencair. Mencairnya es di kutub menyebabkan naiknya suhu dan permukaan air laut. Diperkirakan pada tahun 2100 akan terjadi peningkatan air laut setinggi 15-95 cm akibat mencairnya es di pegunungan dan di kutub Utara-Selatan. Meningkatnya permukaan air laut akan menyebabkan tenggelamnya beberapa daratan dan pulau-pulau kecil.

Berubahnya iklim menyebabkan pergeseran musim di antaranya perubahan pola curah hujan yang berlangsung singkat namun dengan intensitas curah hujan sangat tinggi, mengakibatkan banjir dan longsor. Perubahan tekanan udara yang cukup ekstrem menyebabkan badai dan puting beliung disertai hujan cukup deras. Selain itu, pergeseran musim juga menyebabkan musim kemarau berkepanjangan yang berdampak pada kekeringan, berubahnya pola musim tanam yang merugikan petani karena sulit menentukan saat pembibitan, perkiraan panen dan serangan hama yang tak terduga. Habitat kehidupan terganggu karena pengaruh perubahan iklim. Beberapa spesies bertahan dengan adaptasi namun sebagian yang lain mengalami penurunan jenis bahkan punah.

\begin{tabular}{|l|l|l|l|}
\hline Volume XI & Nomor 01 & Maret 2010 & ISSN 1411-1829 \\
\hline
\end{tabular}


Spesies yang bertahan pada perubahan iklim mulai tampak bermigrasi. Diperkirakan 40 \% dari jumlah total tumbuhan dan hewan telah menggeser lokasi tempat tinggalnya, baik ke arah kutub maupun ke lereng-lereng pegunungan untuk mencoba bertahan di zona hidupnya, sementara sekitar 60 \% lainnya mengubah masa aktivitas seperti masa pembiakan, persemian atau migrasi. Adanya perubahan aktivitas spesies juga menyebabkan meningkatnya penyakit epidemi seperti demam berdarah, malaria karena migrasi vektor penyakit ke permukiman manusia. Meskipun terjadi secara perlahan, perubahan iklim memberikan dampak yang sangat besar pada kehidupan di alam karena tidak ada kawasan yang kebal terhadap perubahan tersebut (Bourne JR, 2008:11).

\section{Penyebab Perubahan Iklim}

$\begin{array}{ccc} & \text { Penyebab utama dari perubahan iklim } \\ \text { adalah } & \text { aktivitas manusia. Manusia }\end{array}$ bertanggungjawab atas penumpukan gas, terutama $\mathrm{CO}_{2}$ melalui pembakaran bahan bakar fosil. Pertambahan penduduk, pesatnya industri dan teknologi menyebabkan aktivitas manusia meningkat yang berdampak juga pada penambahan kontribusi GRK (gas rumah kaca). Setiap negara mempunyai kontribusi GRK tergantung pada aktivitas yang dilakukan penduduknya.

Pemanfaatan energi secara berlebihan terutama energi fosil akan memicu pemanasan global yang berdampak juga pada terjadinya perubahan iklim. Penggunaan bahan bakar fosil seperti minyak bumi, batubara dan gas alam cair akan memicu bertambahnya emisi GRK di atmosfer. Dari ketiga jenis energi yang tersebut di atas, kontribusi $\mathrm{CO}_{2}$ tertinggi di atmosfer adalah batubara. Level $\mathrm{CO}_{2}$ di udara pada tahun 2007 mencapai 384 ppm (tahun 1955, konsentrasi $\mathrm{CO}_{2}$ 315 ppm). Berdasarkan analisis penghitungan terhadap udara purba yang terkurung dalam inti es Antartika, level $\mathrm{CO}_{2}$ saat ini adalah yang tertinggi selama 800.000 tahun terakhir (Kunzig, 2008: 29). Selain emisi yang dihasilkan, perlu diingat bahwa cadangan energi fosil sangat terbatas. Untuk mendapatkan energi fosil tersebut, kita harus menunggu dalam jangka sangat lama, jutaan tahun.
Sektor kehutanan menyumbang emisi GRK tinggi ke atmosfer melalui kegiatan kehutanan dan perubahan kawasan hutan menjadi bukan hutan serta kejadian kebakaran hutan. Seperti diketahui salah satu fungsi hutan adalah sebagai penyerap emisi karbon. Hutan akan menyerap $\mathrm{CO}_{2}$ untuk kegiatan fotosintesis, dan kemudian dikonversi menjadi $\mathrm{O}_{2}$ yang dibutuhkan makhluk hidup. Jika terjadi perubahan dari kawasan hutan menjadi bukan hutan, maka proses penyerapan karbon terhambat dan terlepas ke atmosfer yang memicu pemanasan global dan perubahan iklim.

Sektor pertanian dan peternakan juga memberikan kontribusi terhadap meningkatnya emisi GRK melalui gas metan yang dihasilkan dari sawah yang tergenang dan kotoran hewan serta $\mathrm{N}_{2} \mathrm{O}$ dari pupuk. Pembakaran sisa-sisa pertanian yang membusuk juga merupakan sumber emisi GRK.

Timbunan sampah juga menghasilkan emisi GRK berupa gas metan, meskipun dalam konsentrasi kecil. Tingginya pertumbuhan penduduk memicu aktivitas manusianya yang berdampak juga pada pertambahan volume sampah yang dihasilkan. Jika tidak dikelola secara benar maka akan mempengaruhi konsentrasi gas metan di atmosfer menjadi bertambah. Hal ini akan memicu pemanasan global dan perubahan iklim.

\section{Perubahan Iklim di Indonesia}

Indonesia yang merupakan negara dengan banyak pulau dan beriklim tropis, sangat terpengaruh pada kondisi perubahan iklim. Naiknya permukaan air laut dan suhu air laut menyebabkan terjadi perubahan bagi kehidupan laut dan pesisir. Banyak pulau kecil dan daerah landai di Indonesia akan hilang; hal ini akan menyebabkan mundurnya garis pantai di sebagian besar wilayah Indonesia. Beberapa penelitian menyebutkan bahwa jika tanpa dilakukannya upaya apapun untuk mengurangi GRK, maka pada tahun 2070 akan terjadi kenaikan permukaan air laut setinggi $60 \mathrm{~cm}$. Hal ini menyebabkan mundurnya garis pantai ke arah darat dan mengancam kehidupan masyarakat nelayan yang tinggal di sepanjang pantai. Selain kehilangan tempat tinggal, nelayan akan kehilangan 
tangkapan ikan karena musim yang tidak menentu. Pada masyarakat perkotaan, mundurnya garis pantai, akan mempengaruhi kondisi naiknya salinitas air tanah karena intrusi air laut ke arah daratan.

Naiknya suhu air laut juga mempengaruhi kehidupan terumbu karang. Beberapa jenis ikan yang kehidupannya sangat terpengaruh dan tergantung pada keberadaan terumbu karang akan terpengaruh juga sehingga dengan perubahan iklim akan menyebabkan perubahan komposisi kehidupan laut. Terjadi migrasi ikan yang mempunyai nilai ekonomis tinggi dari perairan Indonesia ke perairan laut di wilayah negara lain yang sesuai dengan kondisi kehidupannya. Beberapa spesies ikan dengan nilai ekonomis rendah, justru mengalami ledakan pertumbuhan. Kondisi ini akan mempengaruhi potensi perikanan Indonesia.

Pada sektor kehutanan, perubahan iklim akan mempengaruhi keadaan flora dan fauna. Peningkatan suhu yang terjadi dalam masa yang cukup lama, seperti musim kemarau panjang dapat meningkatkan peluang terjadinya kebakaran hutan. Musim kemarau panjang telah menyebabkan kebakaran hutan di Indonesia seluas \pm 10 juta ha pada tahun 1997 dan matinya ribuan spesies flora dan fauna di dalamnya. Selain itu, beberapa spesies yang tidak mampu beradaptasi dengan perubahan iklim akan punah, sementara yang mampu bertahan dapat berkembang tidak terkendali.

Tidak menentunya iklim berdampak juga pada turunnya produksi pangan di Indonesia. Semua bentuk sistem pertanian sangat sensitif terhadap variasi iklim. Perubahan musim tanam menyebabkan munculnya hama pertanian yang tidak terduga. Munculnya wereng batang coklat (wbc) akhir-akhir ini merupakan dampak anomali iklim dengan mundurnya awal musim hujan yang menyebabkan terlambatnya awal musim tanam yaitu adanya perubahan pola tanam padi menjadi tidak serentak. Keadaan demikian mempengaruhi ekosistem/lingkungan dan sistem budi daya apalagi ditambah dengan adanya penanaman varietas-varietas peka terhadap wereng batang coklat. Kondisi demikian sangat menguntungkan bagi perkembangan wereng batang coklat, terutama di daerah endemis di mana sumber serangan selalu tersedia setiap saat. Pada kondisi yang menguntungkan populasi wereng batang coklat akan mudah berkembang dan meningkat dengan cepat. Selain daripada itu, perubahan iklim yang berdampak pada tingginya intensitas hujan dalam periode pendek akan menimbulkan banjir yang menyebabkan produksi padi menurun karena sawah terendam air, tanaman-tanaman dari dataran tinggi juga menurun produksinya akibat longsor. Musim kemarau yang panjang juga mempengaruhi produksi pertanian karena lahan yang mengalami kekeringan tidak mungkin untuk ditanami. Ketersediaan pangan di Indonesia menjadi buruk.

Di sektor kesehatan, perubahan iklim menyebabkan berkembangnya beberapa penyakit tropis. Naiknya suhu udara menyebabkan masa inkubasi nyamuk menjadi semakin pendek. Kelembaban yang tinggi mendukung proses metabolisme dan memperpanjang lama hidup nyamuk. Dapat dipastikan nyamuk penyebab penyakit malaria dan demam berdarah berkembang semakin baik. Meledaknya wabah malaria dan demam berdarah di beberapa daerah di Indonesia menjadi kasus KLB (kejadian luar biasa). Pada musim kemarau, kebakaran hutan mempunyai dampak pada penyakit Asma, Bronkhitis/ ISPA (infeksi saluran pernafasan akut) karena terpaparnya asap, debu dan racun dioksin. Selain itu, krisis air bersih pada saat kemarau menyebabkan berkembangnya penyakit kulit. Sebaliknya pada musim hujan dengan intensitas tinggi, menyebabkan banjir. Pada saat banjir, berkembang penyakit kulit, leptospirosis (akibat kencing tikus), diare dan penyakit lain.

Dari uraian di atas, dapat kita lihat bahwa banyak kerugian yang dialami karena perubahan iklim. Indonesia sendiri telah mengalami berbagai permasalahan lingkungan yang terpresentasi sebagai bencana yang dialami hampir secara bertubi-tubi pada dekade terakhir ini. Jika dikaji secara mendalam, pemanasan global dan perubahan iklim yang terjadi berawal dari perilaku manusia dalam memperlakukan alam. Oleh karenanya ketika perubahan iklim telah terjadi, maka tidak satupun upaya yang dapat dilakukan untuk mengembalikan dan memulihkan kondisi ke keadaan semula. Emisi GRK di atmosfer telah meningkat pesat akibat aktivitas manusia. Apapun upaya yang dilakukan, perubahan iklim akan tetap terjadi. Upaya yang 
dapat dilakukan adalah dengan memperlambat proses perubahan iklim sehingga perubahannya tidak dalam bentuk ekstrem, sehingga makhluk hidup dapat beradaptasi dengan perubahanperubahan alam yang terjadi. Selain beradaptasi, manusia dapat melakukan mitigasi terhadap dampak perubahan iklim sehingga dapat menerima resiko sekecil mungkin.

\section{Siklus Carbon}

Carbon merupakan elemen dasar kehidupan; selalu berpindah antara atmosfer, samudra dan daratan. Di atmofer sebagai Carbon dioksida $\left(\mathrm{CO}_{2}\right)$ akan diserap oleh tumbuhan untuk proses fotosintesis. Atmosfer, daratan dan lautan mempunyai simpanan sejumlah besar carbon yang mengeluarkan dan menyerapnya dalam siklus alami seperti siklus air di bumi. Carbon tersimpan pada tumbuhan dan tanah. Pemakaian bahan bakar fosil, penggundulan hutan, pelapukan dan lain-lain mengubah ritme alami memindahkan carbon ke atmosfer.

Proses pembentukan crustasea dan proses geologis (pembentukan batubara dan gas alam) serta adanya lahan hutan membentuk jaringan kompleks siklus carbon yang menyerap sejumlah besar carbon. Jaringan kompleks siklus ini akan mengendalikan $\mathrm{CO}_{2}$ atmosferik yang berpengaruh pada gas rumah kaca (GRK). Siklus carbon ini berjalan secara perlahan dan konstan. Aktivitas manusia dalam satu abad terakhir membuat siklus tersebut berputar terlalu cepat. Manusia mengambil material yang disimpan secara perlahan dalam siklus carbon dan membakarnya dalam bentuk bahan bakar fosil dengan cepat (Kunzig, 2008:36).

\section{Ruang Terbuka Hijau}

Ruang terbuka hijau adalah ruang-ruang terbuka (open spaces) di berbagai tempat di suatu wilayah yang secara optimal digunakan sebagai daerah penghijauan dan berfungsi baik secara langsung maupun tidak langsung untuk kehidupan, kelestarian alam dan keindahan. Secara umum ruang terbuka hijau diisi oleh tumbuhan, tanaman dan vegetasi baik endemik maupun introduksi yang mempunyai manfaat ekologis, sosial budaya dan arsitektural yang dapat memberikan manfaat kesejahteraan bagi masyarakatnya. Secara fisiologis, tanaman bersifat menetralisir kondisi lingkungan. Tumbuhan mempunyai fungsi ekologis sebagai penyerap $\mathrm{CO}_{2}$ yang dipergunakan dalam proses fotosintesis, yang kemudian dari proses tersebut akan menghasilkan Oksigen $\left(\mathrm{O}_{2}\right)$. Selain kemampuan tersebut, tumbuhan jenis pohon dapat menurunkan suhu lokal, memberikan perlindungan terhadap terik sinar matahari, terpaan angin kencang dan juga meredam kebisingan.

Adanya keterkaitan ruang terbuka hijau dan fungsi penyerapan carbon oleh tumbuhan pengisinya, dapat diasumsikan bahwa ruang terbuka hijau merupakan salah satu upaya mitigasi menghadapi perubahan iklim yang diakibatkan pemanasan global. Berdasarkan Konferensi Bumi pada 1992 yang berlangsung di Rio de Jeneiro, Brasil, disepakati setiap negara wajib mengalokasikan luas ruang terbuka hijau sebesar 30\% di setiap kota besarnya. Luasan ini sebagai pertimbangan efisiensi perhitungan minimal carbon yang terserap oleh tumbuhan pengisinya. Hal yang perlu diperhatikan juga adalah jenis tumbuhan pengisinya. Beberapa penelitian menunjukkan bahwa penyerapan carbon oleh tumbuhan sangat tergantung pada jenis, jumlah dan usia tumbuhan tersebut.

\section{Apa yang Harus Dilakukan?}

Dampak perubahan iklim sudah dirasakan oleh manusia. Sebagai manusia yang mempunyai tanggungjawab sosial dan kepedulian terhadap alam yang memberi dan melindungi kehidupan, maka kita harus mempunyai kepedulian pada permasalahan lingkungan yang terjadi di sekitar kita, di antaranya kepedulian pada perubahan iklim yang terjadi dan upaya untuk mengurangi laju perubahan iklim. Perlu integrasi dari berbagai pihak yang terkait, baik pemerintah, sektor swasta/industri dan masyarakat, dalam sosialisasi pemahaman perubahan iklim maupun gerakan aksi nyata untuk memperlambat ataupun mengurangi laju perubahan iklim.

Pada berbagai sektor seperti energi, transportasi dan industri, pemerintah perlu menekankan pentingnya strategi dan aksi nyata 
dalam upaya adaptasi dan mitigasi dalam menghadapi perubahan iklim. Upaya-upaya tersebut antara lain di bidang energi dengan strategi mengganti bahan bakar dengan yang lebih bersih, hemat energi dan ramah lingkungan. Strategi adaptasi terutama di sektor pertanian, perikanan, kehutanan, kesehatan, penambahan dan pelestarian ruang terbuka hijau maupun sektor lain dengan membuat perencanaan dan persiapan dalam menghadapi bencana akibat perubahan iklim, termasuk di dalamnya adalah sistem peringatan dini. Hal ini penting dilakukan supaya masyarakat siap, waspada dan mampu melakukan penanggulangan bencana. Selain itu, strategi melalui upaya penguatan kapasitas masyarakat dengan berbagai penyuluhan, pendidikan dan pelatihan dapat dilakukan untuk membentuk kemandirian masyarakat dalam menghadapi dampak perubahan iklim. Strategi ini sifatnya integrasi di setiap sektor baik di tingkat pusat maupun daerah.

Pola perilaku peduli pada permasalahan perubahan iklim harus ditumbuhkan pada masyarakat karena masyarakat mempunyai kesempatan yang sama dan seluasnya untuk berperan dalam upaya mengurangi laju perubahan iklim. Tanggap segera peduli dapat dimulai dari keluarga masing-masing sebagai komunitas terkecil dalam masyarakat. Dalam kehidupan sehari-hari problematika lingkungan hidup langsung dapat dirasakan akibat pola dan gaya hidup serta penggunaan beberapa sarana fasilitas rumah tangga. Tidak ada tempat yang lebih tepat untuk memelihara lingkungan selain di rumah kita masing-masing, karena di tempat ini kita menghabiskan sebagian besar waktu kita dan dapat memantau semua yang terjadi termasuk bagaimana kita memanfaatkan sumberdaya yang kita konsumsi. Langkah termudah dalam upaya mitigasi menghadapi perubahan iklim sehingga kita terhindar dari problematika lingkungan adalah menambah dan mempertahankan ruang terbuka hijau, sekecil apapun. Pemanfaatan lahan secara efisien sangat membantu kita untuk melestarikan lingkungan terutama dalam upaya mitigasi akibat perubahan iklim. Biasakan tidak menutup/memperkeras halaman dengan semen/tegel dan sebagainya. Lahan yang dipenuhi tanaman atau tanaman dalam pot akan mendatangkan kehidupan alam (kupu-kupu, burung, kadal dan lain sebagainya ) sehingga menambah asri suasana. Hasil dari tanaman obat, sayuran, buah dapat dinikmati sendiri tanpa harus membeli. Selain itu, dengan banyaknya tanaman akan semakin banyak $\mathrm{CO}_{2}$ (karbondioksida) yang terserap.

\section{Kesimpulan}

Perubahan iklim merupakan sebuah fenomena global karena penyebabnya bersifat global, yang disebabkan oleh aktivitas manusia di seluruh dunia. Dampak perubahan iklim dirasakan seluruh makhluk hidup di bumi. Meskipun prosesnya perlahan, dampak perubahan iklim tidak dapat dihindari. Upaya mitigasi dalam menghadapi perubahan iklim adalah menambah dan mempertahankan ruang terbuka hijau. Penanaman pohon memang sangat diperlukan karena kemampuannya menyerap $\mathrm{CO}_{2}$ sebagai salah satu GRK (gas rumah kaca) pemicu pemanasan global yang menyebabkan iklim berubah. Solusi bersifat global dalam bentuk aksi lokal di semua sektor di seluruh dunia. Apa yang tadinya terasa berat akan menjadi biasa dan menjadi pekerjaan yang menyenangkan apabila dikerjakan dengan tulus hati.

\section{Sumber Bacaan}

Anon, Sumberdaya Alam \& Lingkungan Hidup Indonesia, Jakarta : Badan Perencanaan Pembangunan Nasional, 2004.

Anon, "Strategi dan Rencana Tindak Pengembangan Teknologi Pengelolaan Sumberdaya Air yang Efektif dalam Penanggulangan Bencana”. Seminar; Peringatan Hari Air Sedunia, disampaikan Menteri Riset dan Teknologi Republik Indonesia, 2004.

Anon, Bumi Makin Panas, Jakarta : Kementerian Lingkungan Hidup - JICA, 2004.

Anon, tanpa tahun, Remaja Sahabat Alam, Jakarta : Yayasan Garuda Nusantara.

AnonStatus Lingkungan Hidup Indonesia. Jakarta: Kementerian Lingkungan Hidup, , 2007.

Bourne JR, Joel, "Perubahan Telah Tiba”, Perubahan Iklim, terjemahan, National 
Geographic Indonesia, Jakarta : PT. Gramedia Percetakan, 2008.

Koren Herman, Environmental Health and Safety , USA:Lewis Publishers, Inc., 1991.

Krech, D., Richard S.C., and Egerton L.B. Individual In Society.Singapore : McGeaw Hill Book Company, 1988.

Kunzig, Robert., “Terbukti Positif”, Perubahan Iklim, terjemahan, National Geographic Indonesia, Jakarta : PT. Gramedia Percetakan, 2008.

O’neill, T. et al, Bumi Rumah Kaca, terjemahan, Journal Agustus 2007. National Geographic Indonesia, Jakarta : PT. Gramedia Percetakan, 2007.

Riyanto, Budi, Pemberdayaan Masyarakat Sekitar Hutan Dalam Perlindungan Kawasan Pelestarian Alam, Bogor: Lembaga Pengkajian Hukum Kehutanan dan Lingkungan, 2007.

Soemarwoto, Otto, Indonesia Dalam Kancah Isu Lingkungan Global, Jakarta : PT. Gramedia Pustaka Utama, 1991.

Soerjani, M., Arief Yuwono, Dedi Fardiaz, Lingkungan Hidup, Jakarta : IPPL, 2006. 